\title{
高分子/無機柆子複合系溶融体のせん断および伸長流動における 時間一温度換算則の適用
}

\author{
小林 正俊*1 ・高橋 辰宏*1 ・南川慶二*1 ・滝本 淳一*1 ・ 小山 清人*1
}

（受付 1994 年 12 月 26 日・雷查終了 1995 年 5 月 31 日）

\begin{abstract}
要 旨 本研究ではチタン酸カリウムウイスカーを充媜したポリスチレン溶融体の動的粘弾性, 定常せん断粘度 および一軸伸長粘度を $140 \sim 250^{\circ} \mathrm{C}$ の範囲で測定し, 時間一温度換算則を適用した。動的粘弾性の高周波側が一致す るように, そして一軸伸長粘度の線形領域が一致するように決定した移動係数 $a_{T}$ はウイスカーの充填量や变形様 式に依存せず同じ WLF 式で表すことができた。一軸伸長粘度の線形領域では短時間側の增加傾向および長時間側 の定常値ともに良好に 1 本のマスターカーフに一致し，高分子/無機粒子複合系の一軸伸長粘度の線形領域におい て換算則が成立することを確認した。 また，非線形強度の換算ひずみ速度依存性より，換算則が均一系および複合 系の非線形領域においても成立すること示す結果を得た。 ポリスチレン/ウイスカー複合系においてもせん断粘度 と一軸伸長粘度の線形領域に Trouton 則が成立した。
\end{abstract}

\section{1 緒言}

高分子の成形加工において伸長流動が支配的となる過 程は多い，例えば, ブロー成形やフィルム成形, 真空成 形、紡系など, 自由表面が存在する成形過程では伸長流 動が重要となる．せん断流動が支配的な射出成形および 押出成形においても, ダイ入り口部の急縮小流動やキャ ビティー内の流動に伸長流動が関与している.

ポリエチレンやポリスチレンなどの汎用樹脂について は伸長流動の研究が多数報告1) 10) されており，一軸伸 長粘度に対する時間, ひずみ速度, 温度, 分子量, 分子 量分布そして分岐の影響が明らかにされている。これら の研究成果により大変形領域における非線形性（strain hardening 現象）は長時間㖃和機構の存在と密接に関連 するという知見が得られている．また，その長時間緩和 は長鎖分岐や微量の超高分子量成分によると考えられて いる.

長時間緩和が存在するモデル的物質として高分子/無 機粒子複合材料がある.この複合系溶融体は分散粒子の 充寚量が増加するに従って長時間緩和も増加するので, 一軸伸長粘度の非線形性が均一系高分子溶融体よりも顕 著になると予測される。 そこで，著者らはさまざまな種 類の高分子/無機粒子複合系の一軸伸長粘度を測定し検

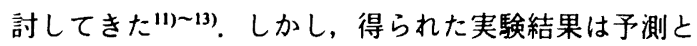
は異なり, 無機粒子の充填量が増加するにつれて非線形 性が隇少する傾向が確認された。篠原 ${ }^{14)}$ も同様な結果

*1 山形大学工学部物質工学科（テ992 山形県米沢市城南 4-316)
を報告している.

時間一温度換算則は高分子のレオロジー的性質の予測 に有用であるが, 過渡的な一軸伸長粘度についての適用 性を報告した(例8), 15), 16) は少ない.さらに，この過渡的 な挙動には線形領域と非線形領域が含まれているため, それぞれの領域に対して換算則が適用できるか否かを確 認する必要がある. 均一系高分子溶融体の一軸伸長粘度 については時間-温度換算則が線形領域において適用で きることが報告されている8. しかし，高分子/無機粒 子複合系についての報告例は見あたらない．また非線形 領域においても適用可能であるかどうかは，均一系か複 合系を問わず明確にはされていないのが現状である．現 存の伸長レオメーターで得られる最高のひずみ速度は $10^{\circ} \mathrm{s}^{-1}$ 程度なので, 換算則が非線形領域においても適 用可能ならば, 高ひずみ速度域における伸長挙動の推定 に用いることができる。

均一系の一軸伸長粘度の線形領域と定常せん断粘度に はTrouton 則17) が成立することが知られている。しか し, 高分子/無機粒子複合系における Trouton 則の適用 に関する研究例は少ない(14). ポリプロピレン/タルク複 合系においては Trouton 則が成立しないと報告(4) され ている. また，高分子/高分子複合系においてもその検 討が行われている(15), 18) 20).

本論文ではチタン酸カリウムウィスカーを充媜したポ リスチレン溶融体の一軸伸長粘度について, 時間-温度 換算則が線形領域と非線形領域の両方に適用できるかど うかを明らかにすることを目的とする．また，Trouton 則が成立しているかどうかも確かめる. 


\section{2 実験方法}

\section{1 試料}

市販のポリスチレン (出光石油化学(株)製 HH-30 重 量平均分子量 $2.6 \times 10^{5}$ ) をマトリックス高分子として用 いた．そして市販のチタン酸カリウムウィスカー（大塚 化学(株) 製 TISMO-D 直径 $0.2 \sim 0.5 \mu \mathrm{m}$, 長さ $10 \sim 20$ $\mu \mathrm{m}$, 比重 3.3〜 3.4）を無機粒子として用いた。 ウィス カーを $1000^{\circ} \mathrm{C} て ゙ 3$ 時間熱処理した後, 二軸混練機によ り各充塤量に応じた割合で混練押出を行いペレット化し た.このペレットを動的粘弾性および定常せん断粘度測 定用の試料とした。 また，一軸伸長粘度測定用試料とし て, 単軸押出機を用いてペレットを丸棒状試料（長さ約 $40 \mathrm{~cm}$, 直径約 $0.3 \mathrm{~cm}$ ) に成形した. ポリスチレンのみ の試料（以下 PS） も同様な方法で成形した。ウィ カ一充垍量は 5 vol\% および 10 vol\%（以下 PSTI-5 およ び PSTI-10）とした.

\section{2 的粘弾性およひ定常せん断粘度測定}

溶融粘弾性装置 (Rheometrics 社製 System-4) を用い て眝蔵弾性率 $G^{\prime}(\omega)$ および損失弾性率 $G^{\prime \prime}(\omega)$ の測定を 行った. 测定温度は $170 \sim 250^{\circ} \mathrm{C}$ 、ひずみの振幅は $10 \%$ と設定し, 振動ひずみの角周波数 $\omega$ は $10^{-2} \sim 10^{2} \mathrm{rad}$. $\mathrm{s}^{-1}$ の範囲で測定した。 また，ストレスレオメーター (Haake 社製 Rheostress RS100) を用いて定常せん断粘 度 $\eta(\dot{\gamma})$ の測定も行った。測定温度は $170^{\circ} \mathrm{C}$ と設定し， 得られたせん断速度 $\dot{\gamma}$ の範囲は $10^{-5} \sim 10^{-3} \mathrm{~s}^{-1}$ であっ た.

\section{3 一轴伸長粘度の測定}

研究室で作製した回転クランプ式伸長レオメータ 一1),2)を用いて一軸伸長粘度 $\eta_{E}^{+}(t, \dot{\varepsilon})$ を測定した。測定 温度 $140 \sim 170^{\circ} \mathrm{C}$ において 10 分間溶融した丸棒状試料を 一定ひずみ速度 $\dot{\varepsilon}$ で伸長した．伸長中における丸棒状 試料の外径変化をビデオ録画し，複合系においても均一 な伸長変形が可能であることを確認した，外径変化から 算出された $\dot{\varepsilon}$ が一定で, 丸棒状試料が均一に变形して いる時間範囲内のデータのみ採用した．算出された は $10^{-3} \sim 10^{-1} \mathrm{~s}^{-1}$ の範囲であった。

\section{3 結果と考察}

\section{1 的弾性率およひ定常せん断粘度}

Fig. 1 には $G^{\prime}(\omega)$ の $170^{\circ} \mathrm{C}$ におけるマスターカーブ を示す.これらのカーブは高周波数側が一致するように 决定している. 図を見やすくするために, PSTI-5 と PSTI-10の $G^{\prime}(\omega)$ については縦軸をPS の值に対してそ れぞれ 1 桁, 2 桁上に平行移動して表示した. ポリスチ レン溶融体に比べてゥィスカー粒子は剛体と見なしてよ く，粒子自身が複合系の剛性率に寄与して系全体の剛性 率が高くなる. 高周波数領域ではそれぞれの試料におい

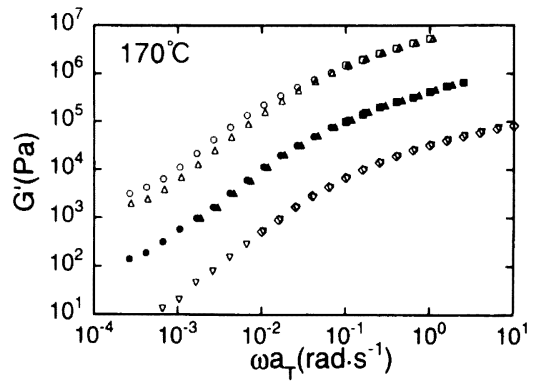

Fig. 1. Master curves of storage modulus for polystyrene and the polystyrene/whisker composite system reduced to $170^{\circ} \mathrm{C}$ : $(\diamond)$ PS $/ 170^{\circ} \mathrm{C} ;(\nabla)$ PS/

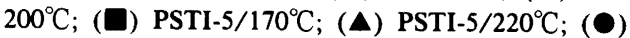
PSTI-5 $/ 250^{\circ} \mathrm{C}$; ( $\square$ ) PSTI- $10 / 170^{\circ} \mathrm{C}$; ( $\triangle$ ) PSTI-10/ $220^{\circ} \mathrm{C}$; (O) PSTI $-10 / 250^{\circ} \mathrm{C}$. The master curves for PSTI-5 and PSTI-10 are shifted upward by a factor of 10 and 100 , respectively.

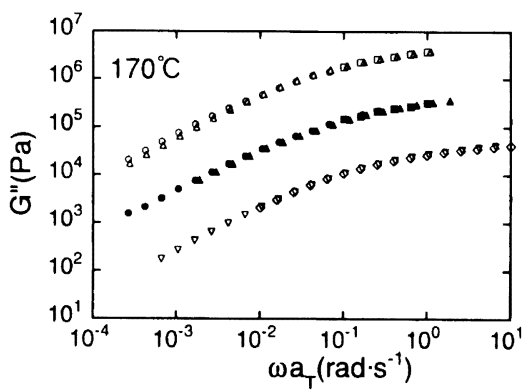

Fig. 2. Master curves of loss modulus for polystyrene and the composites reduced to $170^{\circ} \mathrm{C}:(\diamond)$

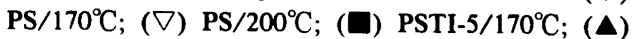
PSTI-5 $/ 220^{\circ} \mathrm{C}$; (○) PSTI-5 $/ 250^{\circ} \mathrm{C}$; ( $\square$ ) PSTI-10/ $170^{\circ} \mathrm{C}$; $(\triangle)$ PSTI- $10 / 220^{\circ} \mathrm{C}$; (O) PSTI- $10 / 250^{\circ} \mathrm{C}$. The master curves for PSTI-5 and PSTI-10 are shifted upward by a factor of 10 and 100 , respectively.

て時間-温度換算則が成立し，1 本の曲線で表すことが できる。低周波数領域においてはPSTI-5 とPSTI-10に 第二平坦部を示す傾向が認められ，その平坦部の $G^{\prime}(\omega)$ はウイスカーの充填量とともに大きくなる傾向を示す. この第二平坦部は粒子充填系に特徴的なむのである.こ の傾向はウイスカーを充媜することによりマトリックス 高分子鎖のからみ合い緩和時間よりあさらに長い緩和時 間が現れることを意味する. また，この低周波数領域に おけるPSTI-10の $G^{\prime}(\omega)$ には時間-温度換算則が厳密に は適用できない. Fig. 2 には $G^{\prime \prime}(\omega)$ の $170^{\circ} \mathrm{C}$ における マスターカーブを示す. $G^{\prime \prime}(\omega)$ む $G^{\prime}(\omega)$ と同様に, PSTI-5 と PSTI-10 については縦軸をPS の值に対してそ 


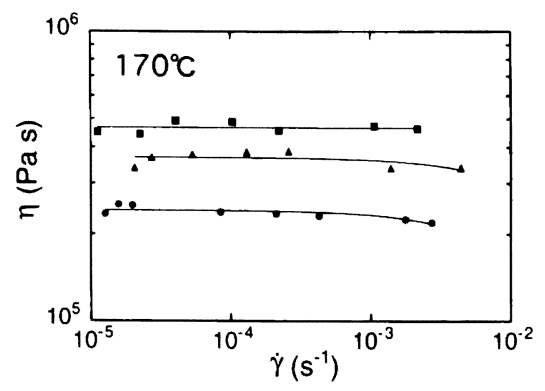

Fig. 3. Shear viscosity as a function of shear rate at

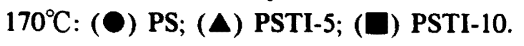

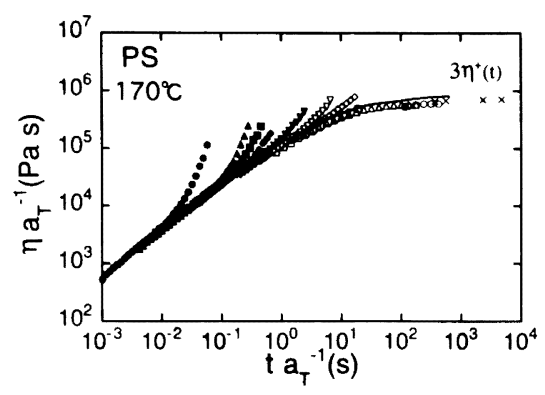

Fig. 4. Master curves of transient uniaxal elongational viscosity as a function of time for PS reduced to $170^{\circ} \mathrm{C}$ at various strain rates $\dot{\varepsilon} a_{T}$ : (O) 52

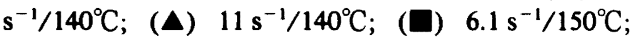

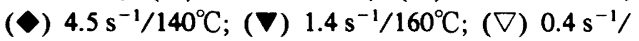
$160^{\circ} \mathrm{C}$; $(\diamond) 0.14 \mathrm{~s}^{-1} / 160^{\circ} \mathrm{C}$; ( $\left.\square\right) 0.066 \mathrm{~s}^{-1} / 170^{\circ} \mathrm{C}$; ( $\triangle) 0.011 \mathrm{~s}^{-1} / 160^{\circ} \mathrm{C}$; (O) $0.0032 \mathrm{~s}^{-1} / 170^{\circ} \mathrm{C}$. The solid line shows $3 \eta^{+}(t)$ calculated from $G^{\prime}(\omega)$ and $G^{\prime \prime}(\omega)$. The crosses show $3 \eta^{+}(t)$ calculated from $\eta(\dot{\gamma})$

れぞれ 1 桁，2桁上に平行移動して表示している. 高周 波数領域及び低周波数領域ともに時間-温度換算則が成 立している. 低周波数領域においても $G^{\prime \prime}(\omega)$ 曲線の勾 配は粒子充填量に依存しない，低周波数領域における換 算則が $G^{\prime}(\omega)$ のみ成立せずに, 高温側での測定値ほど 大きな値を示す傾向はゴム粒子を充填した系においても 報告21),22)されている.

Fig. 3 にはストレスレオメーターによる $\eta(\dot{\gamma})$ を示 す. 複合系の試料においても低せん断速度域において ニュートン領域が観察され, ウイスカーの充填量が増加 するとともにゼロせん断粘度が増加する。

\section{2 一蚰伸長粘度}

$140 \sim 170^{\circ} \mathrm{C}$ の範囲で測定した一軸伸長粘度一時間曲線 のマスターカーブを Fig. 4〜6 に示す. 基準温度 $T_{\mathrm{r}}$ は

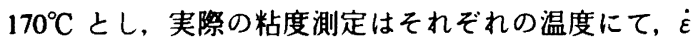
が $10^{-3} \sim 10^{-1} \mathrm{~s}^{-1}$ の範囲で行った. PSのマスターカー

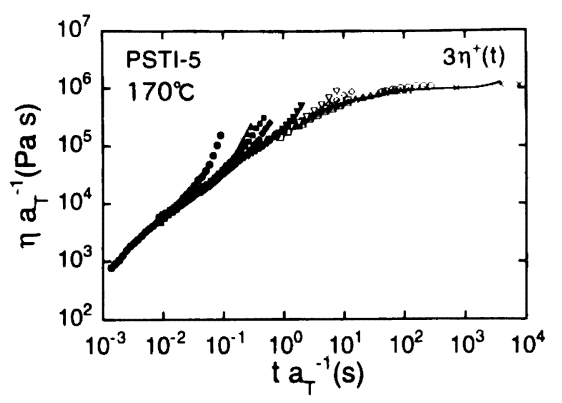

Fig. 5. Master curves of transient uniaxal elongational viscosity as a function of time for PSTI-5 reduced to $170^{\circ} \mathrm{C}$ at various strain rates $\dot{\varepsilon} a_{T}$ : (O) 34 $\mathrm{s}^{-1} / 140^{\circ} \mathrm{C}$; (A) $10 \mathrm{~s}^{-1} / 140^{\circ} \mathrm{C}$; (ロ) $6.6 \mathrm{~s}^{-1} / 150^{\circ} \mathrm{C}$;

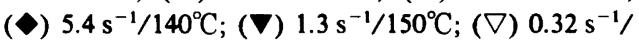

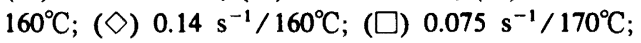
$(\triangle) 0.014 \mathrm{~s}^{-1} / 160^{\circ} \mathrm{C}$; (O) $0.0031 \mathrm{~s}^{-1} / 170^{\circ} \mathrm{C}$. The solid line shows $3 \eta^{+}(t)$ calculated from $G^{\prime}(\omega)$ and $G^{\prime \prime}(\omega)$. The crosses show $3 \eta^{+}(t)$ calculated from $\eta(\dot{\gamma})$.

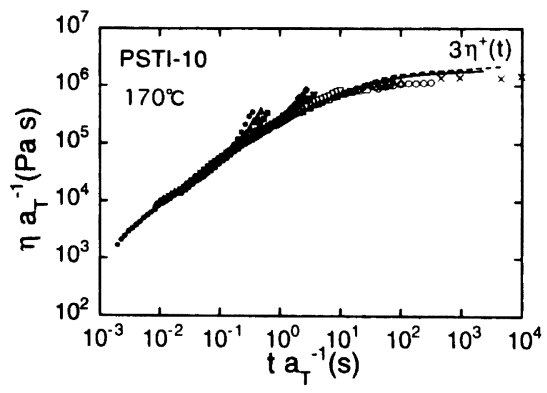

Fig. 6. Master curves of transient uniaxal elongational viscosity as a function of time for PSTI-10 reduced to $170^{\circ} \mathrm{C}$ at various strain rates $\dot{\varepsilon} a_{T}$ : (O) 11 $\mathrm{s}^{-1} / 140^{\circ} \mathrm{C}$; (A) $6.7 \mathrm{~s}^{-1} / 150^{\circ} \mathrm{C}$; (口) $4.9 \mathrm{~s}^{-1} / 140^{\circ} \mathrm{C}$;

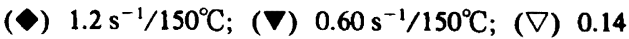

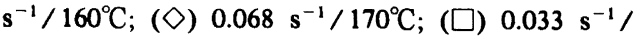
$170^{\circ} \mathrm{C}$; $(\triangle) 0.015 \mathrm{~s}^{-1} / 160^{\circ} \mathrm{C}$; (O) $0.0036 \mathrm{~s}^{-1} / 170^{\circ} \mathrm{C}$. The solid line shows $3 \eta^{+}(t)$ calculated from $G^{\prime}(\omega)$ and $G^{\prime \prime}(\omega)$. The crosses show $3 \eta^{+}(t)$ calculated from $\eta(\dot{\gamma})$.

フの線形領域がそれぞれ良好に一致していることから， 線形領域においては時間-温度換算則が成立しているこ とが認められる. PSTI-5 と PSTI-10のマスターカーブ の線形領域に注目すると, 短時間側の増加挙動及び長時 間側の定常値ともに良好に一致している.したがって， 時間-温度換算則は高分子/無機粒子複合系の一軸伸長粘 度の線形領域にあ適用できることが確認できる.

次に, 非線形領域における換算則の妥当性について検 討を行う. 複合系はもちろん均一系においてさえ, 非線 
高分子/無機粒子複合系溶融体のせん断および伸長流動における時間-温度換算則の適用

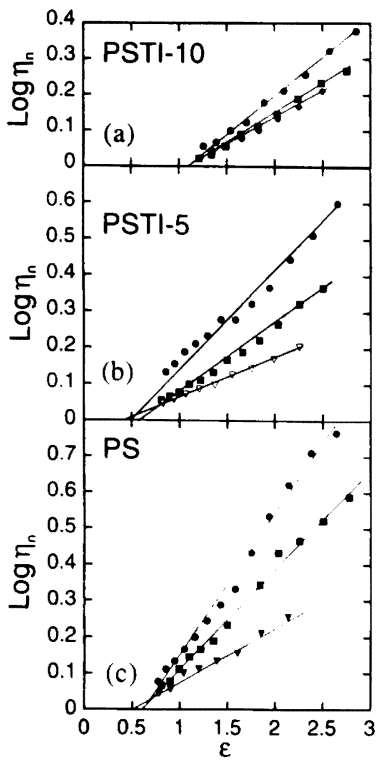

Fig. 7. Nonlinear parameter plotted against Hencky strain at various strain rates $\dot{\varepsilon} a_{T}$ : (a) PSTI-10 (O) $11 \mathrm{~s}^{-1}$; (口) $4.9 \mathrm{~s}^{-1}$; (४) $1.2 \mathrm{~s}^{-1}$, (b) PSTI-5 (O) 34 $\mathrm{s}^{-1}$; (口) $6.6 \mathrm{~s}^{-1}$; ( $\left.\nabla\right) 0.32 \mathrm{~s}^{-1}$, (c) PS (O) $52 \mathrm{~s}^{-1}$; (口) $6.1 \mathrm{~s}^{-1} ;(\nabla) 1.4 \mathrm{~s}^{-1}$. The reference temperature is $170^{\circ} \mathrm{C}$.

形領域における換算則の妥当性を報告した例は見あたら ない．ここでは一軸伸長粘度の非線形性を定量化し，そ の定量化した值の換算ひずみ速度 $\dot{\varepsilon} a_{\mathrm{T}}$ 依存性を調べる ことにする．一軸伸長粘度の非線形性を以下に示す非線

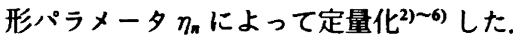

$$
\eta_{\mathrm{n}}=\eta_{\exp } / \eta_{\mathrm{I}}
$$

ここで $\eta_{\exp }$ は任意の時間（ひずみ）における一軸伸長 粘度の実測值である. また, $\eta_{1}$ は対応する時間において 線形粘弾性を仮定したときに示す一朝伸長粘度値であ る. また，均一系高分子については $\eta_{n}$ の対数と Hencky ひずみ $\varepsilon$ との間に直線関係が成立することが実験的に確 認されており 2) 6)，その傾き $\alpha$ は非線形強度と定義さ れ, 次式で表される.

$$
\begin{array}{ll}
\eta_{n}=\exp \left(\alpha \varepsilon^{*}\right) & \\
\varepsilon^{*}=\varepsilon-\varepsilon_{c} & \varepsilon>\varepsilon_{c} \\
\varepsilon^{*}=0 & \varepsilon<\varepsilon_{c}
\end{array}
$$

ひずみ $\varepsilon_{c}$ は線形領域から外れて非線形性が発現する 臨界ひずみである. Fig. 7(a)〜 (c) にそれぞれのマス ターカーフから求めた非線形パラメータ $\eta_{n}$ の対数を Henckyひずみ $\varepsilon$ に対してプロットした. ここではそれ ぞれの試料について 3 種類の $\dot{\varepsilon} a_{T}$ における $\eta_{n}$ を示して いる. 高分子/無機粒子複合系においても $\eta_{n}$ の対数と $\varepsilon$ の間に直線関係が成立し, $\dot{\varepsilon} a_{\mathrm{T}}$ の増加とともに直線の傾

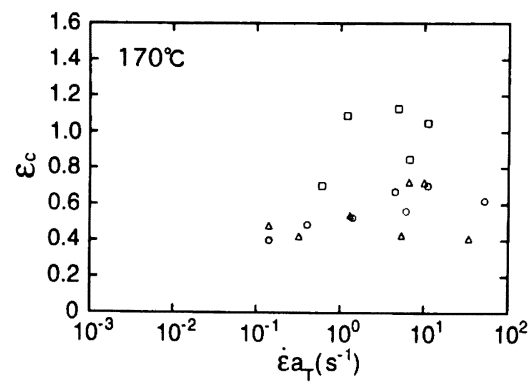

Fig. 8. Critical strain plotted against strain rate $\dot{\varepsilon} a_{T}$ : (O) PS; ( $\triangle$ ) PSTI-5; ( $\square$ ) PSTI-10.

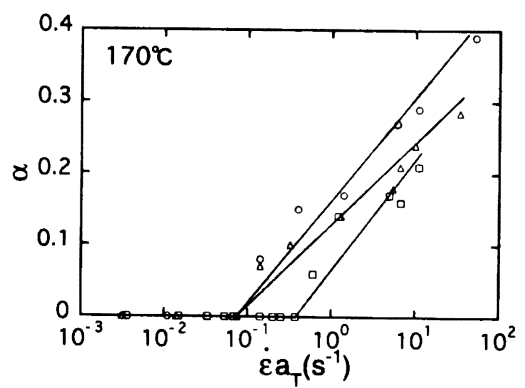

Fig. 9. Nonlinear intensity plotted against strain rate $\dot{\varepsilon} a_{T}$ : (O) PS; ( $\triangle$ ) PSTI-5; ( $\square$ ) PSTI-10.

きが増加することが認められる．このプロットに対し， 最小自乗法により (2) 式をあてはめることで非線形強度 $\alpha$ と臨界ひずみ $\varepsilon_{c}$ を求めた. Fig. 8 に $\dot{\varepsilon} a_{\mathrm{T}}$ に対する $\varepsilon_{\mathrm{c}}$ を示す. PSの $\varepsilon_{\mathrm{c}}$ は $0.4 \sim 0.7$ 程度, PSTI-5については PS とほとんど変わらない. しかし, PSTI-10の $\varepsilon_{\mathrm{c}}$ は大 きく, 0.7〜 1.2 程度である. また, $\dot{\varepsilon} a_{T}$ の影響は明確に は認められない.

Fig. 9 に $\dot{\varepsilon} a_{T}$ に対する非線形強度 $\alpha$ を示す．低ひずみ 速度域では非線形性を示さないので $\boldsymbol{\alpha}$ は 0 であるが, ある臨界ひずみ速度以上からそれぞれの $\alpha$ が增加し始 める. PS はひずみ速度 $0.14 \mathrm{~s}^{-1}$ 以上で非線形性を示し, $\dot{\varepsilon} a_{\mathrm{T}}$ が増加するに従って $\alpha$ がほぼ直線的に増加する. 一 方, PSTI-5 と PSTI-10 が非線形性を示す $\dot{\varepsilon} a_{T}$ は, 前者 が PS と同様に $0.14 \mathrm{~s}^{-1}$ 以上, 後者は $0.60 \mathrm{~s}^{-1}$ 以上であ る. また, 多少ばらつきはあるがそれらもほぼ直線的に 増加している傾向が認められる.これらは異なる4 種類 の温度で測定した $\eta_{B}^{+}(t, \dot{\varepsilon})$ を，線形領域が一致するよう に移動した一軸伸長粘度曲線の $\alpha$ である. それにもか かわらず, 非線形性の程度を示す $\alpha$ がある臨界 $\dot{\varepsilon} a_{T}$ 以 上から増加し，その増加傾向がそれぞれ1本の直線にの ることが確認できる。これは一軸伸長粘度の非線形領域 においても時間-温度換算則が成立していることを示す 結果といえる. 線形領域が一致するように決定したマス 


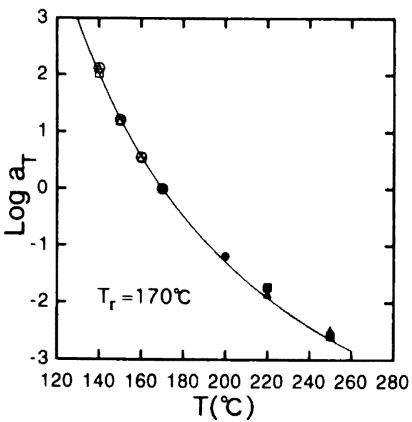

Fig. 10. The shift factor for elongational and shear flow plotted against temperature: $(O)$ PS/Elongation; ( $\triangle$ ) PSTI-5/Elongation; ( $\square$ ) PSTI-10/ Elongation; (O) PS/Shear; (A) PSTI-5/Shear; ( $\square$ ) PSTI$10 /$ Shear. The reference temperature is $170^{\circ} \mathrm{C}$. The solid line represents the WLF equation.

ターカーブにおいて，その非線形性にも換算則が成立し ているということは, 線形領域に寄与する緩和時間と非 線形領域に寄与する緩和時間は同一の温度依存性を持つ ことを示している，つまり，基準温度から任意の温度に 変化すると,すべての緩和時間が基準温度の $a_{T}$ 倍に変 化すると言える. マスターカーブの高ひずみ速度域にお ける粘度曲線は非線形性が著しくなっている。この高ひ ずみ速度域は低温側での測定値であることから，PS の 一軸伸長粘度挙動は測定温度に大きく影響を受けること がわかる. 非線形挙動は低温かつ高ひずみ速度ほど顕著 となり，PSTI-5 と PSTI-10 も同様な結果が認められた。 $170^{\circ} \mathrm{C}$ における PSTI-10 の一軸伸長粘度は実際に測定可 能な $\dot{\varepsilon}$ の範囲内 $\left(0.5 \mathrm{~s}^{-1}\right.$ 以下) で非線形挙動を全く示 さなかったしかし，マスターカーブから，PSTI-10で あ高ひずみ速度で伸長することにより非線形性が得られ ると推定できる.

また，無機粒子充填による長時間緩和の增加は一軸伸 長粘度の非線形性の增加に寄与しないことが認められ, むしろ無機粒子の充填により非線形性が減少している.

\section{3 移勤係数}

Fig. 10 には, $G^{\prime}(\omega), G^{\prime \prime}(\omega)$, および $\eta_{E}^{+}(t, \dot{\varepsilon})$ のマス ターカーブを得るために用いた移動係数 $a_{T}$ を温度 $T$ に 対してプロットしてある. 図中の実線はフィッテングに より得た WLF 式（式(3)）である.

$\log a_{T}=-7.16\left(T-T_{\mathrm{r}}\right) /\left(134.0+-T_{\mathrm{r}}\right)$

ここで基準温度 $T_{\mathrm{r}}$ は $170^{\circ} \mathrm{C}$ である. $G^{\prime}(\omega)$ および $\boldsymbol{G}^{\prime \prime}(\omega)$ の高周波数側が一致するように決定した $a_{T}$ と $\eta_{\mathrm{E}}^{+}(t, \dot{\varepsilon})$ の線形領域が一致するように決定した $a_{T}$ は 1 本の曲線（式 (3)）と良好に一致している。.これらの結 果から $a_{T}$ はウィスカーの充塓量や変形様式に依存しな いことが確認できる.ゴム粒子を充填した系において
も， $a_{T}$ は粒子濃度 ${ }^{22)}$ や变形様式 ${ }^{23)}$ に影響を受けないと 報告されている。

3.4 Trouton 則

一軸伸長粘度の線形領域とせん断粘度の線形領域には 次の関係が成立する.

$\eta_{E}^{+}(t)=3 \eta^{+}(t)$

ここで $\eta_{E}^{+}(t)$ は $\dot{\varepsilon} \rightarrow 0$ における過渡的な一軸伸長粘度, $\eta^{+}(t)$ は $\dot{\gamma} \rightarrow 0$ における成長せん断粘度である.ここで $t \rightarrow \infty$ における式 (4) が Trouton 則 ${ }^{17)}$ となる.

$$
\eta_{E 0}=3 \eta_{0}
$$

また，尾崎ら24)によって導かれた近似式

$$
\begin{aligned}
\eta^{+}(t) \simeq & t\left[G^{\prime \prime}(\omega)+1.12 G^{\prime}(0.5 \omega)\right. \\
& \left.-0.200 G^{\prime}(\omega)\right]_{\omega=1 / 1}
\end{aligned}
$$

を用いることにより $G^{\prime}(\omega)$ および $G^{\prime \prime}(\omega)$ の測定結果か ら $3 \eta^{+}(t)$ を計算することができる. $\eta(\dot{\gamma})$ からは次式に よって計算することができる.

$$
\eta^{+}(t)=\eta(\dot{\gamma})_{\dot{r}=1 / t}
$$

このようにして計算した $3 \eta^{+}(t)$ は均一系高分子溶融 体における $\eta_{E}^{+}(t)$ の実験値を良好に表すことが知られて いる. Fig. 4〜6には式 (4) 加ら計算した値との比较も 行っている. それぞれの曲線と $\times$ 印は $G^{\prime}(\omega)$ および $G^{\prime \prime}(\omega)$ (Fig. 1, 2) ट $\eta(\dot{\gamma})$ (Fig. 3) から計算した $3 \eta^{+}(t)$ である. また, PSTI-10 は低周波数領域における $G^{\prime}(\omega)$ の時間-温度換算則が成立しなかったので, それぞれの 温度で得た測定値ごとに計算した。実線が低温 $\left(220^{\circ} \mathrm{C}\right)$, 破線が高温 $\left(250^{\circ} \mathrm{C}\right)$ で得た $G^{\prime}(\omega)$ より計算し た $3 \eta^{+}(t)$ である. PS と PSTI-5については緩やかな増 加傾向および長時間側の定常値がそれぞれ良好に一致 し, 式 (6) および式 (7) から計算した Trouton 則が成立 していることが確認できる. PSTI-10については $\eta_{B}^{+}(t)$ の緩やかな増加傾向と $3 \eta^{+}(t)$ 曲線が一致する. 定常値 についても $\eta(\dot{\gamma})$ から計算した $3 \eta^{+}(t)$ と良好に一致して いる. また，低周波数領域における $G^{\prime}(\omega)$ の時間-温度 換算則の不成立より， $G^{\prime}(\omega)$ および $G^{\prime \prime}(\omega)$ から計算し $た 3 \eta^{+}(t)$ 曲線と $\eta_{E}^{+}(t)$ は伸長時間 100 秒以上で一致し なくなるが著しい差ではない，以上の結果より，ポリス チレン/ウイスカー複合系においても Trouton 則が成立 することが確認できる.

\section{4 結 論}

ポリスチレン/チタン酸カリウムウイスカー複合系溶 融体の一軸伸長粘度を $140 \sim 170^{\circ} \mathrm{C}$ の範囲で湘定し, 基 準温度 $170^{\circ} \mathrm{C}$ にて時間一温度換算則を適用した. 複合系 溶融体における換算則は一軸伸長粘度の線形領域におい て成立することが確認された。非線形パラメーターの換 算ひずみ速度依存性から，均一系の非線形領域で換算則 が成立することを示す結果が得られた．また，椱合系の 非線形領域においても換算則の成立が示された。 これら 
の結果から，線形領域に寄与する緩和時間と非線形領域 に寄与する緩和時間は同一の温度依存性を持つことが確 認された．移動係数はウイスカーの粒子濃度や変形様式 に依存しないことが認められた. 動的粘弾性測定の結果 からウイスカーを充塤することにより長時間緩和の増加 が認められたが，その増加した成分は一軸伸長粘度の非 線形性の増加には寄与しないことが確認された。 また, ポリスチレン/ウイスカー複合系において Trouton 則の 関係が適用できた.

辞武料の作製に多大のご援助を睗りました出光石油化 学(株)の策原正之氏に感謝いたします. 当時山形大学の竹田 啓先生には終始ご助言を頂きました，感謝いたします。

\section{文献}

1) K. Koyama and O. Ishizuka, Polymer, 21, 164 (1980).

2) K. Koyama and O. Ishizuka, Polym. Proc. Eng., 1, 55 (1983).

3) K. Koyama and O. Ishizuka, 維維学会誌, 38, T-239 (1982).

4）上田基範，小山清人，Mitubishi Kasei R \& D Review, 6, 78 (1992).

5) 小山清人, 石塚 修, 日本レオロジー学会誌, 13, 93 (1985).

6) 小山清人, 石塚 修, 維維学会誌, 37, T-258 (1981).

7) 筆原正之, 日本レオロジー学会誌, 19, 118 (1991).

8) 李 林, 升田利史郎, 高橋雅興, 大野秀樹, 日本レオ ロジー学会誌, 16, 117 (1988).

9) 升田利史郎, 高橋雅興, 大野秀樹, 李 林, 日本レオ ロジー学会誌, 16, 111 (1988).
10) 高橋雅興, 升田利史郎，小野木重治，日本レオロジー学 会誌, 11, 14 (1983).

11）高橋辰宏, 田中佳明, 小林正俊, 南川度二, 小山清人, 岩倉賢次, 竹田 啓, 松田和夫, 成形加工, 93, 198 (1993).

12) M. Kobayashi, K. Minagawa, H. Takeda, K. Iwakura, and K. Koyama, Proceedings Processing Socicty, PPS-Regional Meeting, Tokyo (1993), p. 167.

13）小林正俊, 高橋辰宏, 南川度二, 小山清人, 岩倉賢次, 竹田 啓, 松田和夫, 日本レオロジー学会 第 41 回レオ ロジー討論会講演要旨集, p. 259(1993).

14）篠原正之, 日本レオロジー学会 第 38 回レオロジー討論 会講演要旨集, p. 174 (1990).

15) 服部高明, 瀧川敏算, 升田利史郎, 日本レオロジー学会 誌, 20, 141 (1992).

16) L. Li, T Masuda, and M. Takahashi, J. Rheol., 34, 103 (1990).

17) F. T. Trouton, Proc. Roy. Soc., Ser. A, 77, 426 (1906).

18) T. Takahashi, Y. Takagi, K. Minagawa, and K. Koyama, Polymer, 35, 4472 (1994).

19）田中克史, 小山清人, 渡辺淳, 䋗維学会誌, 50, 41 (1994).

20）服部高明, 荒木 修, 瀧川敏算, 升田利史郎, 日本レオ ロジー学会誌, 第 40 回レオロジー討論会講演要旨集, p. 41 (1992).

21) 青木雄二, 日本レオロジー学会誌, 7, 20 (1979).

22) 升田利史郎, 来田村実信, 小野木重治, 日本レオロジー 学会誌, 8,123 (1980).

23) 斉藤䲩逸郎, 日本レオロジー学会誌, 10, 123 (1982).

24) 尾崎邦宏, 村井 朝, 別所信夫, 金 圆植, 日本レオロ ジー学会誌, 4, 166 (1976).

Application of the Time-Temperature Superposition Principle to the Shear and Uniaxial Elongational Flow for Polymer-Inorganic Particle Composite Melt

Masatoshi KobaYashi*1, Tatsuhiro TaKahashi*1, Keiji MINAGAWA*1, Junichi Takımoto*1, and Kiyohito KoYAMA*1

*1Department of Materials Science and Engineering, Yamagata University (4-3-16, Jonan, Yonezawa, Yamagata, 992 Japan)

Dynamic viscoelasticity, steady state shear viscosity and transient uniaxial elongational viscosity of a polystyrene/ whisker composite melt were measured in the temperature range from $140^{\circ} \mathrm{C}$ to $250^{\circ} \mathrm{C}$. We applied the time-temperature superposition principle to shear and elongational data. The shift factor $a_{T}$ was independent of the whisker content and the deformation style. The time-temperature superposition principle was applicable to the linear region of the uniaxial elongational viscosity for the composite melts. The strain rate dependence of the non-linear intensity indicated that the superposition principle is also applicable to the non-linear region of uniaxial elongational viscosity. In the linear region, the transient elongational viscosity for the composites was found to be very close to three times the shear viscosity.

KEY WORDS Time-Temperature Superposition Principle / Polystyrene / Whisker / Composite / Shear Flow / Elongational Flow /

(Received December 26, 1994: Accepted May 31, 1995)

[Kobunshi Ronbunshu, 52(8), 478-483 (1995)] 